\title{
Host-Parasite Relationship
}

National Cancer Institute

\section{Source}

National Cancer Institute. Host-Parasite Relationship. NCI Thesaurus. Code C16697.

The interactions between two organisms, one of which lives at the expense of the other. $(\mathrm{NCl})$ 